\title{
Connections between abiotic and biotic components of a granite catena ecosystem in Kruger National Park
}

\begin{tabular}{|c|c|}
\hline \multicolumn{2}{|c|}{$\begin{array}{l}\text { Authors: } \\
\text { Beanelri B. Janecke' } \\
\text { Johan van Tol' }\end{array}$} \\
\hline \multicolumn{2}{|c|}{$\begin{array}{l}\text { Affiliations: } \\
{ }^{1} \text { Department of Animal, } \\
\text { Wildlife \& Grassland } \\
\text { Sciences, Faculty of Natural \& } \\
\text { Agricultural Sciences, } \\
\text { University of the Free State, } \\
\text { Bloemfontein, South Africa }\end{array}$} \\
\hline \multicolumn{2}{|c|}{$\begin{array}{l}{ }^{2} \text { Department of Soil, Crop } \\
\text { and Climate Sciences, } \\
\text { Faculty of Natural \& } \\
\text { Agricultural Sciences, } \\
\text { University of the Free State, } \\
\text { Bloemfontein, South Africa }\end{array}$} \\
\hline \multicolumn{2}{|c|}{$\begin{array}{l}\text { Corresponding author: } \\
\text { Beanelri B. Janecke, } \\
\text { janeckbb@ufs.ac.za }\end{array}$} \\
\hline \multicolumn{2}{|c|}{$\begin{array}{l}\text { Received: } 15 \text { June } 2020 \\
\text { Accepted: } 17 \text { June } 2020 \\
\text { Published: } 29 \text { Oct. } 2020\end{array}$} \\
\hline \multicolumn{2}{|c|}{$\begin{array}{l}\text { How to cite this article: } \\
\text { Janecke, B.B. \& Van Tol, J., } \\
\text { 2020, 'Connections between } \\
\text { abiotic and biotic } \\
\text { components of a granite } \\
\text { catena ecosystem in Kruger } \\
\text { National Park', Koedoe 62(2), } \\
\text { a1638. https://doi.org/ } \\
\text { 10.4102/koedoe.v62i2.1638 }\end{array}$} \\
\hline \multicolumn{2}{|c|}{$\begin{array}{l}\text { Copyright: } \\
\text { (c) 2020. The Authors. } \\
\text { Licensee: AOSIS. This } \\
\text { is licensed under the } \\
\text { Creative Commons } \\
\text { Attribution License. }\end{array}$} \\
\hline \multicolumn{2}{|l|}{ Read online: } \\
\hline 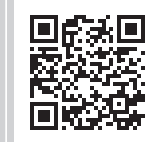 & $\begin{array}{l}\text { Scan this QR } \\
\text { code with your } \\
\text { smart phone or } \\
\text { mobile device } \\
\text { to read online. }\end{array}$ \\
\hline
\end{tabular}

This special issue is a compilation of multidisciplinary articles on a granitic ecosystem in the Stevenson-Hamilton Supersite of Kruger National Park. The majority of research was conducted on a single catena during the same period (2015-2018), to establish connections between abiotic and biotic components. A framework for the multidisciplinary approach is presented and followed by a series of articles focussing on soils, hydrology, microorganisms in rhizospheres, vegetation and mammals.

The catena concept refers to the co-evolution and distribution pattern of different soils along a hillslope, from the crest to the valley bottom. These differences in soils are largely driven by hydrological processes in savanna landscapes. The combination of soils and soil water regimes results in different vegetation patterns along the hillslope gradient, which affects other biotic components such as microorganisms and mammals. The catena in this study is located in a third-order catchment of the Southern Granite Supersite, near Skukuza in the Kruger National Park (KNP). The supersite concept was introduced by Smit et al. (2013) to encourage multidisciplinary research within a specific focus area of the park.

The Special Issue is the product of a dedicated effort to bring eight principle, multidisciplinary research fields together to explore connections between ecosystem components within the same local study area. The underlying hypothesis was that heterogeneity of abiotic and biotic components at catena scale can be better understood and, ultimately, better managed through a multidisciplinary approach. This research has been conducted on a small scale to provide not only a basis for understanding, but also a framework for other similar studies.

During the course of this project, two team members, Dr Fred Kruger and Prof. Johann du Preez, who were giants in ecological research, passed away. The tributes in this issue acknowledge their immense contribution not only to the project but also to natural science in general - our friends, we miss you dearly! Two other colleagues stepped up to help with publishing the results of this project, to whom we are eternally grateful.

The project commenced in 2015 and covered soil types and properties, hydropedological flowpaths, dry mud in depressions (small aquatic organisms), microorganisms and fungi in the rhizosphere of plants, vegetation, mammals, and the ecosystem. During 2015-2016, KNP was badly affected by a severe drought. This impacted collection of certain samples that are dependent on sufficient rainfall to wet the soils, fill temporary pools, or lead to flow in the seep lines on the catena. Samples were taken of dry mud in depressions to search for the presence of small aquatic organisms or their eggs. Unfortunately, the drought hampered this research and no substantial results were obtained. Vegetation structure, composition and mammal presence were still recorded during 2016 and 2017. The drought was partially broken during 2017.

This Special Issue consists of a series of 11 articles and one short communication. It starts with an article, which summarises the main findings of the other articles and highlights connections between the abiotic and biotic trophic levels and components that formed part of this study (Janecke et al. 2020). The Southern Granite Supersite and research that was performed up to this point on the supersite is described in detail by Smit (2020). He also provided an integration of multidisciplinary research as an introduction to this project. The next article describes the morphological and chemical properties of soil types along the catena (Bouwer, Le Roux \& Van Tol 2020). It further provides a conceptualisation of dominant hydrological processes based on the hydropedological interpretation of the spatial distribution of soils. The article by Riddell et al.

Note: Special Issue: Connections between abiotic and biotic components of a granite catena ecosystem in Kruger National Park, subedited by Beanelri Janecke and Johan van Tol. 
(2020) builds on this topic and quantified specific hydrological processes and properties (e.g. evapotranspiration, soil water contents and groundwater recharge). Van Tol et al. (2020) then used the soil and hydrological measurements to predict how changes in rainfall regimes will impact hydrological processes on this catena.

The next article deals with the microbiome of the root zone (rhizosphere) of three plant species growing in different positions on the catena (Vermeulen, Cason \& Swart 2020). The variability of the fungal community structure in the rhizosphere follows on this topic (Gryzenhout et al. 2020a). A short communication wraps up this topic and provides a first report of the presence of various Fusarium species on the catena (Gryzenhout et al. 2020b).

Soil, among other environmental factors, determines the type of vegetation that can grow in specific areas. Different soil types were linked to plant communities and sub-communities distributed along the catena, from the top to the bottom in the third order drainage line (Theron, Van Aardt \& Du Preez 2020). The vegetation structure was also found to differ between the hillslope zones (Janecke 2020), and this led to a variety of habitat types for animals. The impact of the drought on vegetation and the recovery of plants on the catena over a period of 3-4 years were covered in an article by Van Aardt et al. (2020). The variety of habitat types created by different plant communities in the catenal zones were also linked to mammal presence on the catena and at the waterholes in the vicinity (Janecke \& Bolton 2020).

This Special Issue provides a basis for possible future studies that can build on the foundation laid by this project. It also supports the concept encouraged by KNP to focus multidisciplinary research on areas such as the supersites. Systems are unstable, complex and open, with random reactions and different processes that continuously need further research and investigation. We trust that this research will spark the interest of other researchers and emphasise the importance of multidisciplinary studies to provide links and further connections, and in the process fill any gaps in knowledge that might still exist of the various components of an ecosystem.

\section{Acknowledgements}

The research presented in this Special Issue was financially supported by several institutions; each is acknowledged in the specific publications. As guest editors, we would, however, like to acknowledge the University of the Free State Central Research Fund and SANParks for their financial contributions towards publishing the issue, as well as for their vision in supporting the multidisciplinary project which forms the core of articles in this Special Issue. Further, we would like to thank all the reviewers who contributed to the quality of the manuscripts, and our research team (the eight principle researchers, 12 authors from UFS and two from SANParks in associated collaboration with authors from 14 other institutions) for all their hard work, long hours and dedication to this project. Lastly, this issue would not have been possible without the assistance of the friendly staff of SANParks Scientific Services and AOSIS Publishers who were always ready to assist.

\section{Competing interests}

The authors declare that they have no financial or personal relationships that may have inappropriately influenced them in writing this editorial.

\section{References}

Bouwer, D., Le Roux, P.A.L. \& Van Tol, J., 2020, 'Identification of hydropedological flowpaths in Stevenson-Hamilton catena from soil morphological, chemical and hydraulic properties', Koedoe 62(2), a1584. https://doi.org/10.4102/ koedoe.v62i2.1584

Gryzenhout, M., Cason, E.D., Vermeulen, M., Kloppers, G.A.E., Bailey, B. \& Ghosh, S., 2020a, 'Fungal community structure variability between the root rhizosphere and endosphere in a granite catena system in Kruger National Park, South Africa', Koedoe 62(2), a1597. https://doi.org/10.4102/koedoe.v62i2.1597

Gryzenhout, M., Vermeulen, M., Pambuka, G. \& Jacobs, R., 2020b, 'First report of various Fusarium species from the Stevenson-Hamilton Supersite granite catena system in the Kruger National Park, South Africa', Koedoe 62(2), a1599. https://doi. org/10.4102/koedoe.v62i2.1599

Janecke, B.B., 2020, 'Vegetation structure and spatial heterogeneity in the Granite Supersite, Kruger National Park', Koedoe 62(2), a1591. https://doi.org/10.4102/ koedoe.v62i2.1591

Janecke, B.B. \& Bolton, J.G., 2020, 'Variation in mammal diversity and habitat affect heterogeneity and processes of a granite catena', Koedoe 62(2), a1592. https://doi. org/10.4102/koedoe.v62i2.1592

Janecke, B.B., Van Tol, J., Smit, I.P.J., Van Aardt, A.C., Riddell, E.S., Seaman, M.T. et al., 2020, 'Biotic and abiotic connections on a granitic catena: Framework for multidisciplinary research', Koedoe 62(2), a1600. https://doi.org/10.4102/ koedoe.v62i2.1600

Riddell, E.S., Nel, J., Van Tol, J., Fundisi, D., Jumbi, F., Van Niekerk, A. et al., 2020 'Groundwater-surface water interactions in an ephemeral savanna catchment, Kruger National Park', Koedoe 62(2), a1583. https://doi.org/10.4102/koedoe. v62i 2.1583

Smit, I.P.J., Riddell, E.S., Cullum, C. \& Petersen, R., 2013, 'Kruger National Park research supersites: Establishing long-term research sites for cross-disciplinary, multiscaled learning', Koedoe 55(1), Art. \#1107, 7 pages. http://dx.doi.org/10.4102/koedoe. v55i1.1107

Smit, I.P.J., 2020, 'Integrating multi-scaled and multidisciplinary studies: A critical reflection on the Kruger National Park research supersites', Koedoe 62(2), a1586. https://doi.org/10.4102/koedoe.v62i2.1586

Theron, E.J., Van Aardt, A.C. \& Du Preez, P.J., 2020, 'Vegetation distribution along a granite catena, southern Kruger National Park, South Africa', Koedoe 62(2), a1588. https://doi.org/10.4102/ koedoe.v62i2.1588

Van Aardt, A.C., Codron, D., Theron, E.J. \& Du Preez, P.J., 2020, 'Plant community structure and possible vegetation changes after drought on a granite catena in the Kruger National Park, South Africa', Koedoe 62(2), a1585. https://doi.org/10.4102/ koedoe.v62i2.1585.

Van Tol, J., Julich, S., Bouwer, D. \& Riddell, E.S., 2020, 'Hydrological response in a savanna hillslope under different rainfall regimes', Koedoe 62(2), a1602. https://doi. org/10.4102/koedoe.v62i2.1602

Vermeulen, M., Cason, E.D. \& Swart, W.J., 2020, 'The rhizobiome of herbaceous plants in Clovelly and Sterkspruit soils of the Stevenson-Hamilton supersite', Koedoe 62(2), a1596. https://doi.org/10.4102/koedoe.v62i2.1596 